\title{
The Effects of Zinc, Lead and Cadmium Pollution on the Leaf Surface Microflora of Lolium perenne L.
}

\author{
By R. J. F. BEWLEY \\ Department of Botany, University of Bristol, Bristol BS8 $1 U G$
}

(Received 10 July 1978)

\begin{abstract}
The influence of zinc, lead and cadmium contamination on the phylloplane microflora of Lolium perenne growing at various distances from a smelting complex was investigated. Bacteria, yeasts and filamentous fungi were isolated using a leaf washing method, and relative metal tolerance was assessed by the incorporation of zinc, lead and cadmium salts into the growth media. Numbers of fungal propagules were also assessed by direct observation of leaf segments. Non-pigmented yeasts of the genus Cryptococcus were particularly tolerant to the metals, both in vitro and in vivo. Bacteria were less tolerant in vitro, but populations in the field were found even under the highest levels of metal contamination. Filamentous fungi were more tolerant than bacteria to heavy metals in vitro but population levels appeared to be particularly influenced by lead contamination on the leaf surface.
\end{abstract}

\section{INTRODUCTION}

Considerable zinc, lead and cadmium pollution occurs in the vicinity of a smelting complex at Avonmouth, near Bristol, and metal levels have been extensively studied on grass, moss and lichens (Burkitt et al., 1972), in soil and vegetation (Little \& Martin, 1972) and on the leaf surfaces of hawthorn, oak, willow and elm (Little, 1973).

Up to 8000 p.p.m. zinc, 5000 p.p.m. lead and 50 p.p.m. cadmium have been detected on vegetation close to the smelting complex (Little, 1973). On pine saplings and cabbages grown in pots and exposed to contamination near the smelter, the numbers and diversity of micro-organisms were reduced compared with those grown at a control site (Gingell et al., 1976). The aim of the present study was to investigate the influence of this pollution on the phylloplane microflora of a plant of the indigenous vegetation, Lolium perenne L., a common grass found near the smelting complex.

\section{METHODS}

Sampling procedure. Five grass fields numbered 1 to 5 , at approximate distances of $0 \cdot 35,0 \cdot 5,1 \cdot 4,1 \cdot 3$ and $1.85 \mathrm{~km}$, respectively, ENE of the Avonmouth smelting complex, were sampled in November 1976. Field 4 was a little nearer to the smelter than field 3 but slightly out of the main line of sampling. Leaves from three patches of Lolium perenne in each field were collected and placed in sterile containers.

Microbiological assay. Eighty leaf discs were cut from each sample (using a $2.5 \mathrm{~mm}$ diam. punch), placed in a Universal bottle containing $10 \mathrm{ml}$ sterile distilled water with $5 \mathrm{~g}$ glass beads (approx. $3 \mathrm{~mm}$ diam.) and shaken for $10 \mathrm{~min}$ on a wrist action shaker. Samples $(0.1 \mathrm{ml})$ of the suspension and of a 10 -fold dilution were each inoculated separately on to the surface of a series of agar plates. Two basic media were used: Martin's Rose Bengal Streptomycin Agar (MRB; Tuite, 1969) and Tryptic Soy Agar [TSA; 3 g Tryptic Soy

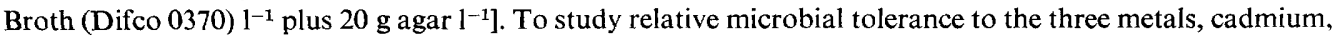
zinc and lead were added singly (as nitrates) at, respectively, 100,400 and $800 \mu \mathrm{g}\left(\mathrm{g}\right.$ wet wt) ${ }^{-1}$ to TSA and $500,2000$ and $2000 \mu \mathrm{g}$ (g wet wt $)^{-1}$ to MRB. Plates of TSA and MRB containing all three metals together in their respective concentrations were also used. For each of the 10 different media, three replicates were 0022-1287/79/0000-8261 \$02.00 (C) 1979 SGM 
prepared for each dilution. The plates were inverted and incubated at ambient temperature (approx. $18{ }^{\circ} \mathrm{C}$ ) for 6 to $15 \mathrm{~d}$ before examination, since isolates tolerant to heavy metals have a somewhat slower growth rate.

Direct observation of fungi. Three leaf segments, each $9 \mathrm{~mm}$ in length, were cut at random from each sample and placed in $4 \%(\mathrm{w} / \mathrm{v})$ chloral hydrate solution. Following clearing, each segment was washed in tap water, stained in phenyl acetic aniline blue (Jones \& Mollison, 1948) for about 7 min, mounted in water and observed with a light microscope (field size of $0.004 \mathrm{~cm}^{2}$ ). Five fields were randomly selected on each surface and the numbers of fungal spores and hyphal fragments, and estimated length of hyphae, were recorded.

Heavy metal assay. Previous work has suggested that most of the total lead burden on the surface of deciduous vegetation near Avonmouth exists as a particulate deposit, but that a proportion of the zinc and cadmium is probably incorporated into the leaf (Little \& Martin, 1972; Little, 1973). Acid washing was used in an attempt to remove the superficial deposits and metal bound to the leaf surface by exchange phenomena. The procedure followed the technique of Little (1973). About 20 leaves of Lolium perenne from the sample used for the microbiological assay were washed in $50 \mathrm{ml} 1 \%(\mathrm{v} / \mathrm{v})$ 'Analar' $\mathrm{HNO}_{3}$ for $1.5 \mathrm{~h}$ on a reciprocating shaker. The washings were decanted and $10 \mathrm{ml}$ concentrated $\mathrm{HNO}_{3}$ were added to each. The leaves were washed again in $50 \mathrm{ml} 1 \% \mathrm{HNO}_{3}$ for $15 \mathrm{~min}$ and these second washings were decanted and treated as above. The washed leaves were dried at $60^{\circ} \mathrm{C}$, weighed, and heated in $4 \mathrm{ml}$ concentrated $\mathrm{HNO}_{3}$ until fully digested. Using an atomic absorption spectrophotometer, each set of washings and the digest was analysed for zinc, lead and cadmium. The values for the two sets of washings were combined to give the 'surface' metal concentration and the total amount of each metal present was calculated by adding the values for the corresponding leaf digests.

\section{RESULTS}

\section{Heavy metal concentrations}

There was a general decrease in the amount of metal pollution with increasing distance from the smelter, from fields 1 to 5 (Fig. 1). The surface and the total levels of zinc were significantly correlated with the corresponding values for lead $(P<0.01)$ but not with those for cadmium. Only total lead, not the surface value, was significantly correlated with total cadmium $(P<0.05)$. The surface metal concentration was generally just over half the total for zinc, and rather more than half for lead. At over half the sites, no cadmium was detected in the leaf tissue following acid washing and at one site, no cadmium was detected at all.

\section{Micro-organisms isolated}

Filamentous fungi and yeasts were isolated on MRB plates. The former consisted almost entirely of Cladosporium spp., Diplodina sp. and the Arthrinium state of Apiospora montagnei Sacc. At all but two sites, at least $75 \%$ of the total yeast population consisted of Cryptococcus sp. Sporobolomyces roseus Kl. \& van Niel, Rhodotorula sp. and Aureobasidium pullulans (de Bary) Arnaud were also isolated but they generally represented only a small proportion of the total.

Of the three filamentous fungi, Diplodina sp. was the least tolerant to lead, tolerant isolates being obtained from one site only (Table 1). All three fungi occurred on at least some of the plates supplemented with zinc and cadmium but not on plates containing all three metals (Table 1). On this medium the total filamentous fungi was composed entirely of a sterile dark mycelium. It is possible that this sterile mycelium may have been sterile Cladosporium spp. although it has remained sterile despite subculturing on to normal metal-free agar, and even after exposure to ultraviolet light. Cryptococcus spp. were isolated from all of the plates containing only one metal and from some of the plates containing all three metals.

On plates supplemented with zinc or cadmium, but not lead, the total numbers of filamentous fungi often exceeded those on the controls. This was also true, to some extent, with the yeasts. 


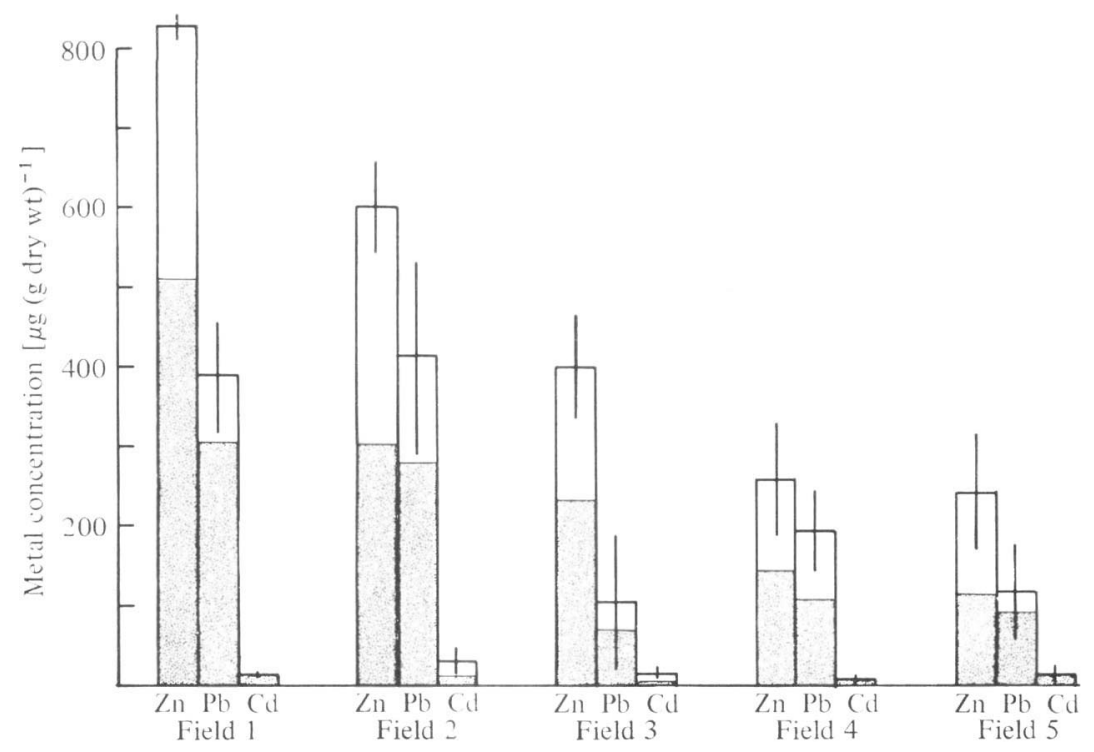

Fig. 1. Mean levels of total zinc, lead and cadmium $\left[\mu \mathrm{g}(\mathrm{g} \text { dry } \mathrm{wt})^{-1}\right]$ present on Lolium perenne, showing standard errors between the three sites in each field. The approximate distances of fields 1 to 5 from the smelter were $0.35,0.5,1.4,1.3$ and $1.85 \mathrm{~km}$, respectively. The shaded area represents the proportion of the total metal removed by surface acid washing.

There were $10^{4}$ to $10^{5}$ bacteria $\mathrm{cm}^{-2}$ of leaf (both surfaces). On the control plates, nonpigmented rods predominated and orange chromogens usually accounted for less than onefifth of the total. Although most of the bacteria on zinc, lead or cadmium media were colourless, they produced an orange non-diffusible pigment when subcultured on to normal metal-free media. A later study of the bacterial flora of contaminated Lolium perenne during April 1978 suggested that pink chromogens were also particularly tolerant to zinc and cadmium, although they accounted for less than $5 \%$ of the total bacteria on control plates.

Yeasts also grew on the TSA plates, and an estimate of their number was made for each replicate. On the control plates, they accounted for only $6 \pm 0.5 \%$ of the total number of colonies. On plates with zinc, they accounted for $22 \pm 1 \%$, with cadmium about $25 \pm 3 \%$ and with lead about $31 \pm 2 \%$. However, when all three metals were added to the media, no bacteria were isolated at all and only a white yeast, identified as Cryptococcus sp., grew (at a mean level of $3.0 \pm 0.9 \times 10^{3}$ organisms $\mathrm{cm}^{-2}$ ).

\section{Effects of heavy metals on the microflora}

Correlation coefficients for the total numbers of micro-organisms on control plates without added metals against the levels of zinc, lead and cadmium on the leaves were calculated (Table 2). The total numbers of bacteria showed a significant positive correlation with both the surface and total levels of zinc and lead. Each of the three fungi showed a positive correlation with the total level of zinc, but only Arthrinium and Cladosporium spp. were significantly correlated with the total lead. Neither fungi nor bacteria showed any significant correlation with the levels of cadmium. Yeast numbers on MRB showed no relationship with the levels of zinc, lead and cadmium.

The percentage of tolerant isolates was calculated at each site from the data in Table 1; these values were compared with the surface and total levels of the corresponding metal on leaves, and correlation coefficients were calculated. The proportion of tolerant bacteria showed no relationship with the corresponding levels of each metal, even after discounting the yeasts present on TSA. Yeast tolerance on MRB and tolerant Cryptococcus sp. on TSA 
Table 1. Mean numbers of micrc-crganisms $\mathrm{cm}^{-2}$ and corresponding numbers of metaltolerant isolates for each field, with standard errors between the three sites

\begin{tabular}{|c|c|c|c|c|c|c|c|c|}
\hline \multirow[b]{2}{*}{$\begin{array}{c}\text { Metal } \\
\text { supplement }\end{array}$} & \multirow[b]{2}{*}{ Field } & \multirow{2}{*}{$\begin{array}{c}\text { Growth } \\
\text { on TSA* } \\
10^{-4} \times \\
\text { Bacteria } \dagger\end{array}$} & \multicolumn{6}{|c|}{ Growth on MRB* } \\
\hline & & & $\begin{array}{c}\text { Total } \\
\text { filamentous } \\
\text { fungi }\end{array}$ & $\begin{array}{c}10^{-3} \times \\
\text { Total } \\
\text { yeasts }\end{array}$ & Diplodina & $\begin{array}{l}\text { Clado- } \\
\text { sporium }\end{array}$ & $\begin{array}{l}\text { Arthri- } \\
\text { nium }\end{array}$ & $\begin{array}{l}10^{-3} \times \\
\text { Crypto- } \\
\text { coccus }\end{array}$ \\
\hline None & $\begin{array}{l}1 \\
2 \\
3 \\
4 \\
5\end{array}$ & $\begin{array}{r}11 \cdot 4 \pm 4 \cdot 3 \\
7 \cdot 6 \pm 1 \cdot 7 \\
6 \cdot 0 \pm 1 \cdot 3 \\
6 \cdot 4 \pm 1 \cdot 7 \\
2 \cdot 8 \pm 0 \cdot 7\end{array}$ & $\begin{array}{r}209 \pm 55 \\
72 \pm 43 \\
58 \pm 27 \\
65 \pm 27 \\
3 \pm 1\end{array}$ & $\begin{array}{r}2 \cdot 8 \pm 0.4 \\
2 \cdot 2 \pm 1 \cdot 0 \\
8 \cdot 7 \pm 0.9 \\
11 \cdot 2 \pm 4.9 \\
1 \cdot 2 \pm 0.9\end{array}$ & $\begin{array}{r}100 \pm 66 \\
13 \pm 9 \\
35 \pm 19 \\
8 \pm 6 \\
0\end{array}$ & $\begin{array}{r}33 \pm 5 \\
25 \pm 13 \\
9 \pm 5 \\
30 \pm 11 \\
1 \pm 1\end{array}$ & $\begin{array}{r}62 \pm 20 \\
32 \pm 22 \\
14 \pm 8 \\
27 \pm 10 \\
1 \pm 1\end{array}$ & $\begin{array}{r}2.6 \pm 0.6 \\
1 \cdot 7 \pm 0.7 \\
6 \cdot 2 \pm 1 \cdot 2 \\
10.2 \pm 4.7 \\
0.7 \pm 0.5\end{array}$ \\
\hline Zinc & $\begin{array}{l}1 \\
2 \\
3 \\
4 \\
5\end{array}$ & $\begin{array}{r}12 \cdot 8 \pm 4 \cdot 9 \\
10 \cdot 7 \pm 3 \cdot 2 \\
9 \cdot 3 \pm 4 \cdot 9 \\
5 \cdot 2 \pm 2 \cdot 0 \\
2 \cdot 0 \pm 0 \cdot 9\end{array}$ & $\begin{array}{r}112 \pm 39 \\
125 \pm 67 \\
136 \pm 17 \\
226 \pm 69 \\
41 \pm 15\end{array}$ & $\begin{array}{l}2 \cdot 3 \pm 1 \cdot 3 \\
2 \cdot 1 \pm 0 \cdot 6 \\
4 \cdot 9 \pm 1 \cdot 2 \\
9 \cdot 3 \pm 4 \cdot 5 \\
2 \cdot 6 \pm 1 \cdot 0\end{array}$ & $\begin{array}{r}18 \pm 10 \\
11 \pm 7 \\
42 \pm 21 \\
103 \pm 51 \\
20 \pm 16\end{array}$ & $\begin{array}{r}17 \pm 10 \\
6 \pm 2 \\
11 \pm 9 \\
6 \pm 4 \\
0\end{array}$ & $\begin{array}{r}76 \pm 33 \\
108 \pm 73 \\
82 \pm 6 \\
111 \pm 18 \\
21 \pm 5\end{array}$ & $\begin{array}{l}2 \cdot 2 \pm 1 \cdot 3 \\
1 \cdot 8 \pm 0 \cdot 6 \\
4 \cdot 4 \pm 1 \cdot 2 \\
8 \cdot 4 \pm 4 \cdot 5 \\
2 \cdot 2 \pm 1 \cdot 0\end{array}$ \\
\hline Lead & $\begin{array}{l}1 \\
2 \\
3 \\
4 \\
5\end{array}$ & $\begin{array}{c}8 \cdot 9 \pm 3 \cdot 3 \\
3 \cdot 8 \pm 0 \cdot 8 \\
3 \cdot 0 \pm 0 \cdot 8 \\
4 \cdot 5 \pm 1 \cdot 2 \\
1 \cdot 2 \pm 0 \cdot 5\end{array}$ & $\begin{array}{r}28 \pm 8 \\
28 \pm 16 \\
7 \pm 1 \\
21 \pm 5 \\
7 \pm 5\end{array}$ & $\begin{array}{l}1 \cdot 2 \pm 0 \cdot 8 \\
1 \cdot 2 \pm 0 \cdot 3 \\
2 \cdot 8 \pm 1 \cdot 1 \\
3 \cdot 4 \pm 1 \cdot 4 \\
1 \cdot 1 \pm 0 \cdot 3\end{array}$ & $\begin{array}{c}0 \\
3 \pm 3 \\
0 \\
0 \\
0\end{array}$ & $\begin{array}{r}17 \pm 9 \\
10 \pm 2 \\
3 \pm 1 \\
3 \pm 3 \\
3 \pm 1\end{array}$ & $\begin{array}{r}10 \pm 8 \\
16 \pm 16 \\
8 \pm 4 \\
19 \pm 6 \\
4 \pm 4\end{array}$ & $\begin{array}{l}1 \cdot 1 \pm 0 \cdot 7 \\
0 \cdot 8 \pm 0 \cdot 3 \\
2 \cdot 7 \pm 1 \cdot 1 \\
3.2 \pm 1 \cdot 4 \\
0.9 \pm 0 \cdot 3\end{array}$ \\
\hline Cadmium & $\begin{array}{l}1 \\
2 \\
3 \\
4 \\
5\end{array}$ & $\begin{array}{l}2 \cdot 3 \pm 1 \cdot 1 \\
1 \cdot 8 \pm 0 \cdot 4 \\
1 \cdot 8 \pm 0 \cdot 6 \\
1 \cdot 1 \pm 0 \cdot 7 \\
0 \cdot 2 \pm 0 \cdot 1\end{array}$ & $\begin{array}{r}321 \pm 22 \\
246 \pm 167 \\
250 \pm 58 \\
304 \pm 110 \\
72 \pm 40\end{array}$ & $\begin{array}{l}2 \cdot 1 \pm 0 \cdot 7 \\
2 \cdot 0 \pm 0 \cdot 2 \\
5 \cdot 2 \pm 1 \cdot 6 \\
9 \cdot 1 \pm 5 \cdot 2 \\
2 \cdot 2 \pm 0 \cdot 5\end{array}$ & $\begin{array}{r}55 \pm 45 \\
7 \pm 7 \\
51 \pm 9 \\
32 \pm 4 \\
34 \pm 30\end{array}$ & $\begin{array}{r}164 \pm 21 \\
33 \pm 13 \\
31 \pm 6 \\
32 \pm 8 \\
9 \pm 3\end{array}$ & $\begin{array}{r}102 \pm 47 \\
207 \pm 157 \\
167 \pm 73 \\
238 \pm 99 \\
29 \pm 8\end{array}$ & $\begin{array}{l}2.0 \pm 0.7 \\
1.8 \pm 0.2 \\
4.6 \pm 1.6 \\
8.4 \pm 5 \cdot 2 \\
2 \cdot 0 \pm 0.5\end{array}$ \\
\hline $\begin{array}{l}\text { All three } \\
\text { metals }\end{array}$ & $\begin{array}{l}1 \\
2 \\
3 \\
4 \\
5\end{array}$ & $\begin{array}{l}0 \\
0 \\
0 \\
0 \\
0\end{array}$ & $\begin{array}{r}3 \pm 1 \\
3 \pm 1 \\
1 \pm 1 \\
9 \pm 5 \\
17 \pm 8\end{array}$ & $\begin{array}{c}0.03 \pm 0.01 \\
0.03 \pm 0.01 \\
0 \\
0.11 \pm 0.11 \\
0.01 \pm 0.01\end{array}$ & $\begin{array}{l}0 \\
0 \\
0 \\
0 \\
0\end{array}$ & $\begin{array}{l}0 \\
0 \\
0 \\
0 \\
0\end{array}$ & $\begin{array}{l}0 \\
0 \\
0 \\
0 \\
0\end{array}$ & $\begin{array}{c}0.03 \pm 0.01 \\
0.03 \pm 0.01 \\
0 \\
0.10 \pm 0.10 \\
0.01 \pm 0.01\end{array}$ \\
\hline
\end{tabular}

* TSA, Tryptic Soy Agar; MRB, Martin's Rose Bengal Streptomycin Agar.

$\dagger$ Numbers of bacteria include a few yeasts present on TSA.

Table 2. Correlation coefficients for the regression of total numbers of micro-organisms against the levels of zinc, lead and cadmium on the leaves at each of the 15 sites

\begin{tabular}{|c|c|c|c|c|c|c|c|}
\hline \multirow[b]{2}{*}{ Medium } & \multirow[b]{2}{*}{ Micro-organisms } & \multicolumn{2}{|c|}{ Zinc } & \multicolumn{2}{|c|}{ Lead } & \multicolumn{2}{|c|}{ Cadmium } \\
\hline & & Surface & Total & Surface & Total & Surface & Total \\
\hline TSA & Bacteria & $0.723^{* *}$ & $0.634^{*}$ & $0.679 * *$ & $0.688 * *$ & -0.003 & 0.173 \\
\hline MRB & Total filamentous fungi & $0.799 * * *$ & $0.756 * *$ & 0.297 & 0.427 & -0.067 & $0 \cdot 108$ \\
\hline MRB & Arthrinium & $0.590^{*}$ & $0 \cdot 660 * *$ & 0.408 & $0 \cdot 588^{*}$ & -0.038 & 0.289 \\
\hline MRB & Diplodina & 0.485 & $0.548^{*}$ & $0 \cdot 048$ & $0 \cdot 104$ & -0.087 & -0.065 \\
\hline MRB & Cladosporium & 0.435 & $0.547^{*}$ & 0.400 & $0 \cdot 586^{*}$ & $0 \cdot 017$ & $0 \cdot 261$ \\
\hline MRB & Total yeasts & -0.146 & $-0 \cdot 190$ & $-0 \cdot 178$ & -0.056 & -0.094 & -0.085 \\
\hline MRB & Cryptococcus & $-0 \cdot 145$ & $-0 \cdot 182$ & -0.118 & -0.002 & $-0 \cdot 114$ & -0.113 \\
\hline
\end{tabular}

* Significant at $P<0.05$. ** Significant at $P<0.01$. *** Significant at $P<0.001$.

$\uparrow$ Correlation coefficients for bacterial numbers were calculated using the total numbers present on TSA. These figures included the yeasts present. However, even when these yeasts were not included in the total, the correlation coefficients were not significantly different. 

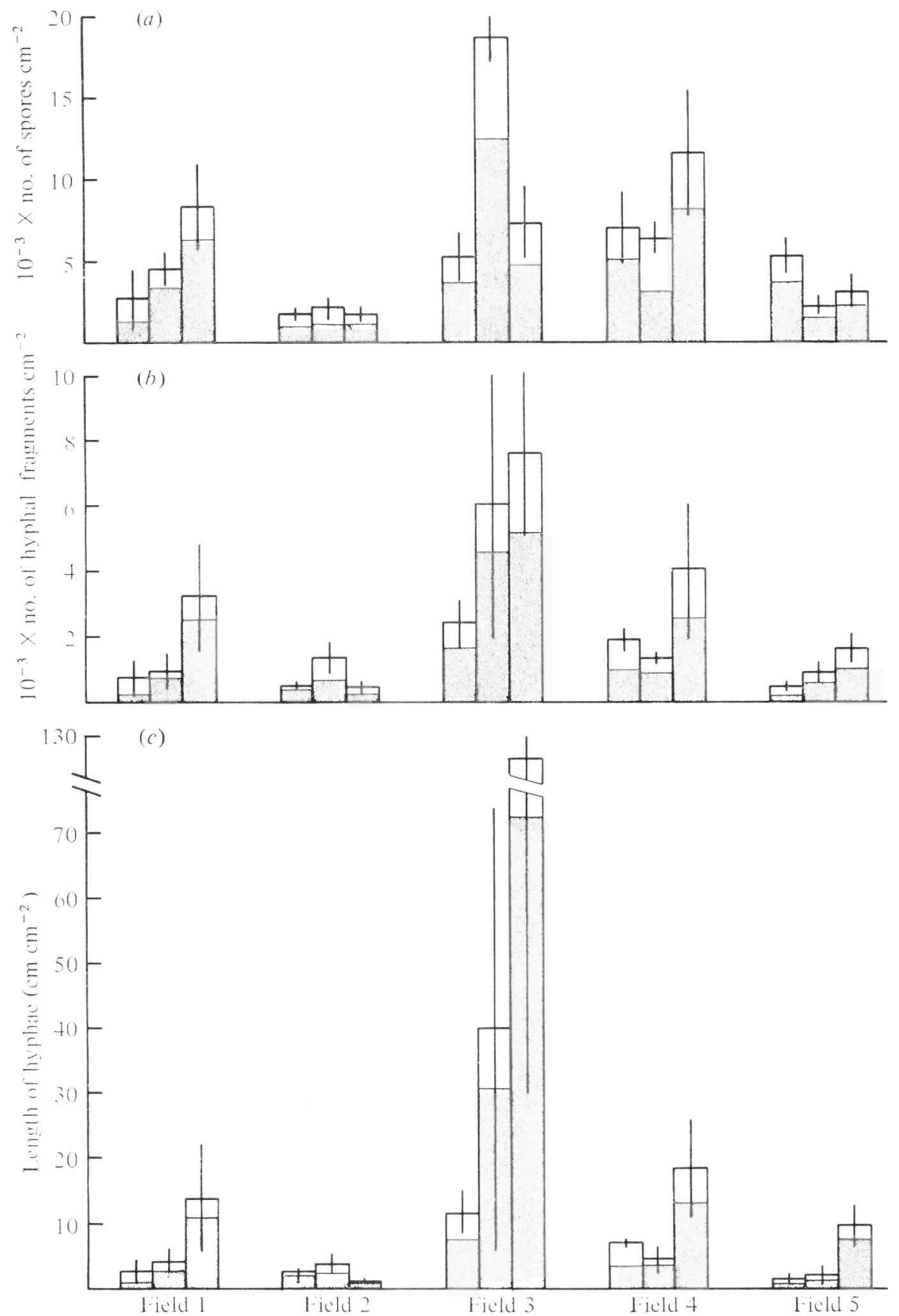

Fig. 2. Bar diagrams showing total fungal propagules $\mathrm{cm}^{-2}$ of leaf, as estimated by direct observation, for each site. Vertical lines indicate the standard errors between three leaf segments. The shaded area represents numbers on the lower surfaces, the unshaded area, numbers on the upper surfaces. (a), Number of spores; $(b)$, number of hyphal fragments; $(c)$, length of hyphae. 
Table 3. Correlation coefficients for the regression of total numbers of fungal propagules $\mathrm{cm}^{-2}$ (counted by direct observation) against the levels of zinc, lead and cadmium

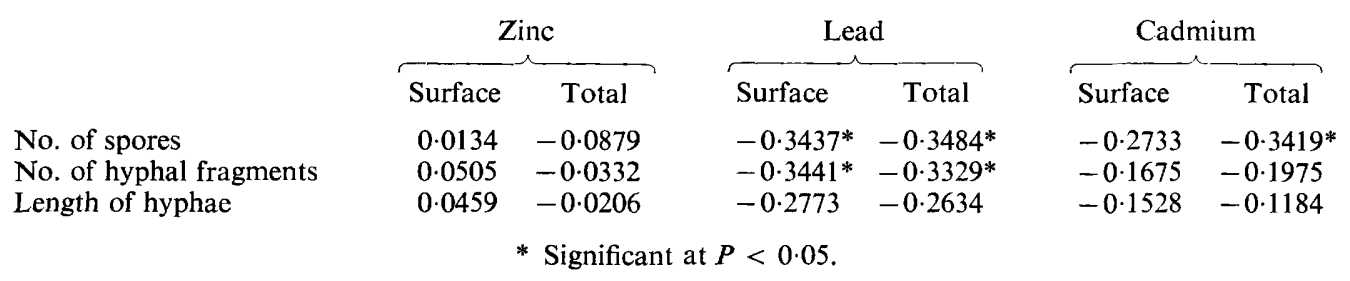

with all three metals were also not significantly correlated with the corresponding metal levels. The percentage of fungi tolerant to all three metals (the sterile dark mycelium) showed a positive correlation with surface levels of cadmium $(r=0.761$, significant at $P<0.01$ ). No other relationships were established between fungal tolerance and the degree of pollution except for Cladosporium spp., where a correlation coefficient of 0.739 (significant at $P<0.01$ ) was obtained between levels of total lead and the percentage of leadtolerant isolates; for surface lead levels, the correlation coefficient was 0.912 (significant at $P<0.001$ ).

\section{Direct observation of fungi}

The total numbers of spores and hyphal fragments usually ranged from $10^{3}$ to $10^{4}$ and from $10^{2}$ to $10^{4} \mathrm{~cm}^{-2}$, respectively (Fig. $2 a, b$ ). At one of the sites in field 3 , however, the number of fungal spores exceeded $1 \cdot 7 \times 10^{4}$; only 15 p.p.m. of surface lead were detected at this site. At another site in the same field, where no surface lead was detected at all, the number of fungal propagules was also high and, in particular, some leaf segments from this field had extensive mycelial growth (up to $317 \mathrm{~cm} \mathrm{~cm}^{-2}$ ) whereas in most other samples hyphae were usually present as discrete fragments $\left(1 \cdot 2\right.$ to $40 \mathrm{~cm} \mathrm{~cm}^{-2}$; Fig. $\left.2 c\right)$. Overall, both the numbers of spores $\mathrm{cm}^{-2}$ and the numbers of hyphal fragments $\mathrm{cm}^{-2}$ were significantly negatively correlated with both the surface and total levels of lead $(P<0.05$; Table 3). The negative correlation of hyphal length with lead, however, was not significant. No significant correlations were established between the numbers of fungal propagules, or hyphal length, and the levels of surface zinc or cadmium, although the total cadmium was significantly negatively correlated with the numbers of fungal spores.

\section{DISCUSSION}

The levels of zinc, lead and cadmium present on Lolium perenne were of the same order as in previous studies (Burkitt et al., 1972). There was less of a reduction in contamination with distance from the smelter than had been expected. The rather erratic variation of cadmium levels may be partly attributed to sampling errors inherent in taking a small weight of leaf tissue for analysis (about $0.1 \mathrm{~g}$ dry wt), and also sampling was carried out during a month of heavy rainfall which may have washed off, or redistributed, a proportion of the surface burden.

The levels of metals recorded in the field were not the same as in the media used to test tolerance. The latter were chosen on the basis of previous studies of the soil microflora from this area of heavy metal pollution and from a control site. Samples of the microflora from each of these areas had been subjected to a range of concentrations of zinc, lead and cadmium and, at certain levels, the differences in tolerance between the two samples became very pronounced (S. Shales, personal communication); these concentrations were adopted in the present study. Since it is impossible to say how much of each metal added to the media is actually available to the inoculum, or how much is available on the leaf surface, 
we cannot make comparisons between the effects of levels in vitro and in vivo. The concentrations in the media were therefore chosen to demonstrate different degrees of tolerance in the organisms rather than to attempt to mimic the natural environment.

In general, the micro-organisms isolated were similar to those from previous studies of Lolium perenne (Dickinson et al., 1975; Austin et al., 1978) and other temperate plants (Last \& Deighton, 1965; Preece \& Dickinson, 1971; Dickinson \& Preece, 1976).

There were quantitative and qualitative changes in the microbes isolated when metals were incorporated into the media. Later experiments which incorporated comparable levels of $\mathrm{KNO}_{3}$ in the control media suggested that any stimulation of numbers was due to the nitrate and not the heavy-metal ion. Smith (1977) also observed a similar phenomenon. The comparison of tolerance between sites is still valid, however, since all propagules were subject to the same stimulating effect for a particular metal.

The most striking qualitative change occurred when TSA plates were supplemented with all three metals. The failure to isolate bacteria and the growth of a single Cryptococcus sp. may have been due to a genuine synergistic effect, whereby the combined effects of two or more of the metals exceeded the sum total of the individual effects. Ramamoorthy \& Kushner (1975) have demonstrated the capacity of liquid microbial growth media to bind large quantities of heavy metal ions. One type of metal ion may be bound preferentially, and on solid media this problem will be accentuated by additional binding by the agar. An alternative explanation to synergism, therefore, could be that when all three metals were added simultaneously, because of differences in the relative ability of zinc, lead and cadmium to compete for agar binding sites, the most toxic of the three may be rendered more available than the other two. Work by Gingell et al. (1976) also suggested that non-pigmented yeasts were far more tolerant to heavy metals than were pigmented yeasts and bacteria, when inoculated on to plates containing all three metals. However, when tolerance to the three metals was tested singly, in the present study, orange pigmented bacteria predominated, and there is no evidence to suggest that the total numbers of bacteria or yeasts (measured in plates without metals) were reduced by heavy metals in the environment even on the most contaminated leaves. Furthermore, bacterial tolerance in vitro was not related to the levels of metal present in the field. This was true for the percentage of tolerant yeasts isolated on MRB and also for the numbers of tolerant Cryptococcus $\mathrm{sp}$. isolated from TSA plates containing all three metals. There are two explanations for this. Firstly, sufficient numbers of suitable uncontaminated microsites for bacterial colonies may occur on the leaf surface. Alternatively, populations of bacteria may have developed which are tolerant to levels of the three metals present on the leaf but not to those levels available in the media containing all three metals. The total numbers of bacteria in fact showed a positive correlation with levels of zinc and lead present in vivo. The reason for this is not clear but it is possible that particulate pollutants may have damaged the leaf surface, increasing the leaching of nutrients from within the plant and resulting in a subsequent stimulation of growth.

A significant negative correlation was observed between the numbers of fungal spores or hyphal fragments (counted by direct observation) and the levels of both surface and total lead contamination. Cladosporium spp. appeared to have developed some degree of tolerance under conditions of high lead pollution. Of the three metals, it is therefore lead which has had the greatest effect on the fungi, and it appears to have exerted more influence on the fungal population on the leaf surface than on the bacteria, even though the latter are inherently much less tolerant. A single fungal hypha is more likely to come into contact with a greater variation in levels of lead on the leaf than a single bacterial cell. This in turn may affect its growth and physiology and influence spore production. Varying degrees of growth inhibition by trace metals have been shown in vitro for different species of pathogenic and saprophytic phylloplane fungi isolated from trees exposed to general urban pollution (Smith, 1977; Staskawicz \& Smith, 1977; Smith et al., 1978). 
Comparisons of the results from direct observation of fungal propagules with the numbers present on the dilution plates suggests that the latter gives a very poor and unreliable indication of the total mycoflora. Leaf washing is known to be an unreliable method for assessing filamentous fungi, and probably only removes spores (Dickinson, 1971). In addition, rapid growth of Cryptococcus sp. on the plates may have obscured developing fungal colonies and the inherent selectivity of the medium was another problem. The numbers of Arthrinium and Cladosporium spp. as estimated from the dilution plates were positively correlated with the total levels of lead. However, since these numbers represent such a small fraction of the total mycoflora, they do not invalidate the general conclusion, from direct observation, that fungi are negatively correlated with lead.

The present study therefore indicates that overall populations of micro-organisms on the Lolium perenne leaf surface are surprisingly little influenced by quite high levels of heavy metal pollution, though there are some differences between micro-organisms in the degree of tolerance. The complexity of microbiological, physical and chemical interactions on the leaf surface has once again been underlined by this study.

I am most grateful to Dr R. Campbell for his advice and helpful discussion. I should also like to thank Dr M. H. Martin for useful discussion and help in sampling Lolium perenne. I am also grateful to $\mathrm{Mr} \mathrm{R}$. J. Allen for technical assistance and to Commonwealth Smelting Limited for access to their land. Finally, I should like to thank the Natural Environment Research Council for a Research Studentship.

\section{REFERENCES}

Austin, B., Goodfellow, M. \& Dickinson, C. H. (1978). Numerical taxonomy of phylloplane bacteria isolated from Lolium perenne. Journal of General Microbiology 104, 139-155.

Burkitt, A., Lester, P. \& Nickless, C. (1972). Distribution of heavy metals in the vicinity of an industrial complex. Nature, London 238, 327-328.

Dickinson, C. H. (1971). Cultural studies of leaf saprophytes. In Ecology of Leaf Surface Microorganisms. Edited by T. F. Preece \& C. H. Dickinson, pp. 129-137. London: Academic Press.

Dickinson, C. H. \& Preece, T. F. (editors) (1976). Microbiology of Aerial Plant Surfaces. London: Academic Press.

Dickinson, C. H., Austin, B. \& Goodfellow, M. (1975). Quantitative and qualitative studies of phylloplane bacteria from Lolium perenne. Journal of General Microbiology 91, 157-166.

Gingell, S. M., Campbell, R. \& Martin, M. H. (1976). The effect of zinc, lead and cadmium pollution on the leaf surface microflora. Environmental Pollution 11, 25-37.

Jones, P. C. T. \& Mollison, J. E. (1948). A technique for the quantitative estimation of soil micro-organisms. Journal of General Microbiology 2, 54-69.

Last, F. T. \& Deighton, F. C. (1965). The nonparasitic microflora on the surfaces of living leaves. Transactions of the British Mycological Society 48, 83-99.

Little, P. (1973). A study of heavy metal contamination of leaf surfaces. Environmental Pollution 5, 159-172.

Little, P. \& Martin, M. H. (1972). A survey of zinc, lead and cadmium in soil and natural vegetation around a smelting complex. Environmental Pollution 3, 241-254.

Preece, T. F. \& Dickinson, C. H. (editors) (1971). Ecology of Leaf Surface Microorganisms. London: Academic Press.

Ramamoorthy, S. \& Kushner, D. J. (1975). Binding of mercuric and other heavy metal ions by microbial growth media. Microbial Ecology 2, 162-176.

SмiтH, W. H. (1977). Influence of heavy metal leaf contaminants on the in vitro growth of urban tree phylloplane fungi. Microbial Ecology 3, 231-239.

Smith, W. H., Staskawicz, B. J. \& Harkov, R. S. (1978). Trace metal pollutants and urban-tree leaf pathogens. Transactions of the British Mycological Society 70, 29-33.

Staskawicz, B. J. \& Smith, W. H. (1977). Trace metal lead pollutants suppress in vitro development of Gnomonia platani. European Journal of Forest Pathology 7, 51-58.

Turte, J. (1969). Plant Pathological Methods. Minneapolis: Burgess Publishing Company. 